\title{
ANALISIS PERAN KEAGAMAAN TERHADAP PROSES PENDIDIKAN KURSUS BAHASA INGGRIS (Studi Kasus di Kampung Inggris Pare Kediri Jawa Timur)
}

\author{
Muhamad Abdul Aziz \\ Sekolah Tinggi Ilmu Ekonomi Solusi Bisnis Indonesia \\ Jl. Ringroad Utara No.17, Condongcatur, Depok, 55283, Sleman \\ E-mail:azizannawawi@gmail.com

\begin{tabular}{c|c|c}
\hline Received: & Revised: & Approved: \\
$07 / 08 / 2017$ & $28 / 11 / 2017$ & $04 / 12 / 2017$ \\
\hline
\end{tabular}

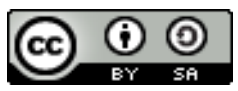 \\ Analisis Peran Keagamaan Terhadap Proses Pendidikan Kursus Bahasa \\ Inggris (Studi Kasus di Kampung Inggris Pare Kediri Jawa Timur) \\ is licensed under a Creative Commons Attribution-ShareAlike 4.0 \\ International License.
}

\begin{abstract}
Abstrak
Pare merupakan salah satu daerah koordinator kecamatan di Kabupaten Kediri. Pare termasuk daerah yang telah berkembang secara pesat, dan dikenal sebagai Kampung Bahasa, atau Pusat Pelatihan Bahasa Asing terbesar diIndonesia. Paper ini adalah kajian yang berbasis penelitian lapangan (field research) Paper ini bertujuan untuk mengetahui peranan keagamaan didalam pendidikan kursusan berbasis bahasa pada siswa di Kampung Inggris. Penelitian ini sangat menarik karena Pendidikan kursus berbasis bahasa dikaji dalam hubungan nya dengan ke agamaan, dimana peserta didik sebagai objek sentralnya. Selanjutnya, penelitian ini adalah jenis penelitian deskripstif kualitatif yang dilakukan selama 3 bulan pada tanggal 1 Juni 2015. Populasi dari penelitian ini adalah semua kursus lembaga yang ada di kampung Inggris Pare Kediri. Data penelitian diperoleh
\end{abstract}


melalui wawancara, observasi dan dokumentasi. Pada paper ini terdapat tiga persoalan yang hendak di kaji pertama, sejauh mana proses belajar agama di Kampung Inggris setelah banyaknya warga pendatang?Kedua, sejauh mana proses belajar agama dikawasan yang wajib berbahasa Inggris? Ketiga, sejauh mana peranan lingkungan Kampung Inggris terhadap proses belajar agama di kampung Inggrs? Maka dihasilkan beberapa hal, yaitu pertama, mengetahui sejauh mana proses belajar agama di Kampung Inggris setelah banyaknya warga pendatang. Kedua, mengetahui sejauh mana proses belajar agama dikawasan yang wajib berbahasa Inggris, ketiga mengetahui peranan lingkungan Kampung Inggris terhadap proses belajar agama di kampung Inggris.

Kata Kunci : Keagamaan, Pendidikan Bahasa, dan Kampung Inggris.

\begin{abstract}
Pare is one area in Kediri district coordinators. Pare including areas that had been growing rapidly, and is known as Kampung Language, Foreign Language Training Center or the largest companies. This paper is based on field research study (field research) This paper is based on field research study (field research) This paper aims to determine the role of religion in education kursusan language based on the student at Kampung Inggris. This research is very interesting because of the language-based education courses examined in its relations with all religious, where the learner as the central object. Furthermore, this study is the kind of qualitative research conducted deskripstif for 3 months on June 1, 2015. The population of this research is all of course agencies in the village Pare. Data were obtained through interviews, observation and documentation. In this paper, there are three issues to be investigated The first, the extent to which the process of religious learning in Kampung Inggris after the immigrant population? Secondly, how far has the area of religious study is required to speak English? Third, the extent to which the role of the British village environment to the learning process in the village Inggrs religion? Then produced a couple of things: first, determine the extent of religious learning process in Kampung Inggriss after the immigrant population. Second, determine the extent of religious learning process that must speak English region, three British Kampung know the role of the environment on the process of religious learning in the British village.
\end{abstract}

Keywords: Religious, Language Education, and Kampung Inggris. 


\section{A. Pendahuluan}

Penelitian ini berangkat dari fenomena isu sosial di lingkungan Pare Kediri, yang berawal dari munculnya wacana peranan keagamaan di dalam proses pendidikan belajar bahasa di kampung Inggris Pare. Menurut Yaya Suryana dan Rusdian, Pendidikan diharapkan mampu menjadikan dewasa, karena dewasa merupakan ciri manusia yang memiliki karakter. Oleh karena itu, setiap orang dewasa memiliki karakter sesuai dirinya sendiri. Dengan demikian perlu pendidikan untuk mendorong seseorang menjadi diri sendiri. ${ }^{1}$ Dari pernyataan ini, jelas bahwa lingkungan sangat besar peranannya terhadap perilaku seseorang. Kampung Inggris, adalah salah satu contoh tempat yang bisa mengubah perilaku seseorang menjadi lebih baik, bukan hanya lebik baik dalam menguasai percakapan bahasa Inggris, tetapi juga mampu membentuk pribadi yang luhur dan pribadi yang agamis. Jika ada orang ditempatkan di sebuah lembaga kursusan, maka secara otomatis dia akan mengubah perilaku dan ibadahnya menjadi pribadi yang agamis.

Belajar dan mengajar merupakan dua konsep yang tidak dapat dipisahkan satu sama lain. Belajar menunjukan apa yang harus dilakukan seseorang sebagai subjek yang menerima pelajaran (sasaran didik), sedangkan mengajar menunjukan apa yang harus dilakukan oleh guru sebagai pengajar. Dua konsep tersebut menjadi terpadu dalam satu kegiatan manakala terjadinya interaksi gurusiswa, pada saat pengajaran itu berlangsung. Inilah makna belajar dan mengajar sebagai suatu proses. Interaksi guru dan siswa dalam proses pembelajaran memegang peranan penting untuk mencapai tujuan pembelajaran yang efektif. Mengingat kedudukan siswa sebagai subjek dan sekaligus juga sebagai objek dalam pembelajaran maka inti proses pembelajaran tiada lain adalah kegiatan belajar siswa dalam mencapai suatu tujuan pembelajaran. ${ }^{2}$

Banyak sekali metode pendidikan yang ditawarkan oleh para pakar pendidikan, namun tidak semuanya dapat diaplikasikan dengan maksimal. Oleh karna itu, adalah penting sekali bagi setiap

1 Yaya Suryana \& H. A. Rusdian, Pendidikan Multikultural, (Bandung :CV Pustaka Setia, 2015), 260.

2 Ahmad Sabri, Strategi Belajar Mengajar Micro Teaching, (Padang: Quantum Teaching, 2007), 31. 
guru memahami sebaik-baiknya tentang proses belajar murid, agar ia dapat memberikan bimbingan dan menyediakan lingkungan belajar yang tepat dan serasi bagi murid-murid. ${ }^{3}$ hendaknya seorang pendidik terlebih dahulu untuk mempertimbangkan metode apa yang kiranya tepat untuk digunakan yang dapat mempengaruhi proses belajar yang lebih baik dan relevan dengan materi yang akan disampaikan. Selain itu penggunaan metode yang kreatif dan inovatif menjadi pertimbangan seorang pendidik guna meningkatkan minat siswa dalam belajar. Pendidikan Islam merupakan sistem pendidikan untuk melatih anak didiknya sedemikian rupa sehingga dalam sikap hidup, tindakan dan pendekatanya, terhadap segala jenis pengetahuan banyak yang dipengaruhi oleh nilai-nilai spiritual dan sangat sadar akan nilai etik Islam. ${ }^{4}$

Proses pendidikan agama yang selama ini hanya bergantung melalui aktivitas pengajaran, maka untuk efektifnya perlu dikembangkan melalui aktivitas pendidikan, sehingga kegiatan pendidikan agama seharusnya dapat juga berlangsung di luar dinding kelas. Aktivitas pendidikan agama yang selama ini lebih menuntut kegiatan intelektual, maka untuk dapat meningkatkan efektivitasnya, kegiatan pendidikan agama seharusnya diwarnai kegiatan lainnya, termasuk praktek beribadah dan muamalah dengan cara yang bijak, sebagai wujud pengembangan aspek personal dan sosial peserta didik, karena kedua aspek tersebut sangatlah penting dalam kehidupan setiap inividu di tengah-tengah masyarakat. Bahkan lebih jauh lagi manfaat dari proses yang demikian itu akan mendukung terbangunnya masyarakat humanis dan pluralis.

Di sisi lain juga, pendidikan agama selama ini memang lebih banyak dijadikan tanggung jawab orang tua, dibandingkan pemerintah. Sementara mata pelajaran kuliah pendidikan agama yang selama ini ada dinilai menghadapi berbagai keterbatasan. Sebagian masyarakat menghadapinya dengan tambahan pendidikan agama dirumah-rumah ibadah atau diperkumpulan-kumpulan yang kemudian berkembang menjadi satuan atau program pendidikan 2009), 27

Oemar Hamalik, Proses Belajar Mengajar(Jakarta: PT Bumi Aksara, 2000), 79 .

${ }^{4}$ Ismail SM, dkk, Paradigma Pendidikan Islam (Yogyakarta: Pustaka Pelajar, 
keagamaan formal, nonformal atau informal. ${ }^{5}$ Seharusnya, guru lebih kreatif dan bertanggung jawab penuh terhadap siswa-siswanya, karna bukan hanya menambah wawasan terhadap pengetahuan agama tetapi juga Islam memuliakanya.

Salah satu hal yang amat menarik pada ajaran Islam ialah penghargaan Islam yang sangat tinggi terhadap guru. Begitu tingginya penghargaan itu sehingga menempatkan kedudukan guru setingkat dibawah kedudukan Nabi dan Rasul. Penghargaan Islam yang tinggi kepada guru tidak bisa dilepaskan karena Islam sangat menghargai ilmu pengetahuan. ${ }^{6}$

Dewasa ini bahwa penilaian yang dilakukan untuk pendidikan agama cenderung lebih mengandalkan pada penilaian kognitif. Itu pun kadang-kadang juga masih dilakukan modifikasi. Padahal untuk idealnya, penilaian yang semacam itu belumlah cukup, bahkan jauh dari ideal. Sesuai dengan hakekat pendidikan agama, yang menjadi targetnya bukanlah aspek kognitif saja. Jika demikian maka penilaian seharusnya dilakukan terhadap semua aspek dengan menempatkan pengamalan menjadi aspek yang penting dan menentukan. Dengan kata lain keberhasilan dan kegagalan pendidikan agama sangatlah bertumpu pada pengamalan agama peserta didik. Sesungguhnya Islam mengharapkan dari seorang muslim untuk bekerja sebelum berbicara, tidak mengatakan sesuatu melainkan untuk dikerjakan dan tidak bekarja melainkan untuk diselesaikan dengan sebaik-baiknya. ${ }^{7}$

Bahkan lebih jauh dari itu, apabila pendidikan agama sebagai kunci dari bidang studi lainnya dalam setiap satuan pendidikan, maka penilaian agama seharusnya dilakukan lebih berhati-hati dan dapat dipertanggung jawabkan, baik secara moral maupun akademik. Namun yang menjadi persoalan adalah tidak jarang pendidikan agama justru dipakai sebagai "back up" pendidikan yang sulit dipertanggungjawabkan. Artinya bahwa pendidikan agama hanya dipakai untuk legalisasi yang lainnya, bahkan untuk kepentingan

5 Abdurrahman al-Nahlawi, Pendidikan Islam di Rumah, Sekolah, dan Masyarakat (Jakarta: Gema Insan Press, 1995), 176. 2004), 177.

6 Khoiron Rosyadi, Pendidikan Profetik (Yogyakarta: Pustaka Pelajar,

7 Yusuf Al-Qardhawy, Pendidikan Islam dan Madrasah Hasan al-Banna (Jakarta: Bulan Bintang, 1980), 101. 
dakwah. Praktek-praktek pendidikan yang demikianlah yang sebenarnya menyulitkan siapapun yang bertanggung jawab dalam pelaksanaan pendidikan agama. Menyadari akan kondisi obyektif pelaksanaan pendidikan agama di lapangan, yang paling esensial adalah semuanya itu dilakukan dengan penuh tanggung jawab dan tetap berorientasi kepada apresiasi yang proporsional terhadap eksistensi peserta didik, sehingga mereka akan siap menjadi anggota masyarakat yang bermartabat.

\section{B. Pembahasan}

\section{Peranan Lingkungan Kampung Inggris}

Peranan adalah suatu pola tingkah laku yang merupakan ciri-ciri khas semua petugas dari suatu pekerjaan atau tugas tertentu. Adapun peranan yang penulis maksudkan adalah suatu usaha atau tindakan yang dilakukan guru dalam memberikan pertolongan atau pendidikan kepada anak didiknya agar mengalami suatu perubahan ${ }^{8}$

Selanjutnya, menurut Kamus Besar Bahasa Indonesia (KBBI) yang dimaksud lingkungan adalah daerah (kawasan dan sebagainya) yang termasuk didalamnya. Sedangkan lingkungan secara umum diartikan sebagai kesatuan ruang dengan segala benda, daya, keadaan, dan makhluk hidup, termasuk manusia dan perilakunya, yang mempengaruhi kelangsungan perikehidupan dan kesejahteraan manusia serta mahluk hidup lainnya. ${ }^{9}$

Di antara pengaruh lingkungan terhadap seseorang adalah keluarga yang Islami dalam pembentukan karakter atau kepribadian seseorang. Sejatinya jika membahas kajian lingkungan setidaknya ada 3 lingkungan kaitannya dengan pendidikan Islam, yaitu lingkungan keluarga, lingkungan sekolah, dan lingkungan masyarakat. Dalam ruang lingkupkeislaman, artinya sejauh manakah lingkungan Islam dalam memberikan kontribusinya dalam memelihara umatnya untuk selalu berada jalan Allah swt dari tinjauan filsafat pendidikan Islam, dan lingkungan pendidikan Islam dalampembentukan karakter.

\footnotetext{
${ }^{8}$ Departeman Pendidikan dan Kebudayaan, Bimbingan dan Penyuluhan (Jakarta: Gaya Tunggal, 1980), 23.

${ }^{9}$ Burhani MS, Hasbi Lawrens, Kamus Ilmiah Populer (Jombang: Lintas Media, 2001), 355.
} 
Lingkungan adalah suatu tempat dimana seseorang itu hidup dan berkembang. Jika dihubungkan dengan lingkungan Islam maka suatu keadaan yang selalu dipengaruhi oleh ajaran-ajaran Islam atau berkarakteristik keislaman adalah lingkungan Islami, Artinya keadaan lingkungan yang berkarakter Islami sesuai dengan tuntunan Allah dan Rasulullah. Jadi, untuk menciptakan masyarakat yang baik diperlukan lingkungan yang baik pula. ${ }^{10}$

Jadi bisa di ambil sebuah pengertian bahwa lingkungan pendidikan Islam adalah suatu tempat yang memungkinkannya berkembangnya seseorang secara normal sehingga mampu meningkatkan kualitas diri, dan mengaktualisasikan diri berdasarkan ajaran-ajaran agama Islam.Pendidikan agama Islam yang didukung oleh lingkungan pada saat ini menjadi pembicaraan yang cukup hangat, sebagai pengembangan sistem pendidikan yang ada di Indonesia. Dimana pendidikan dirasakan oleh pemerintah telah mengalami degradasi yang menjadikan pemerintah melakukan berbagai upaya pengembangan pendidikan yang sudah berjalan selama ini.Pendidikan agama Islam adalah upaya untuk membentuk budi pekerti atau perilaku yang tercermin dalam kata, perbuatan, sikap, pikiran, perasaan, kerja, dan hasil karya berdasarkan nilai, norma dan moral luhur bangsa Indonesia melalui kegiatan bimbingan, pengajaran dan latihan. Selain itu, pendidikan agama adalah mengacu pada serangkaian sikap, perilaku, motivasi dan keterampilan.

Adapun Hakikat Kampung Inggris sejatinya Kampung Inggris bukanlah nama resmi sebuah desa atau wilayah. Kampung Inggris hanyalah julukan atau sebutan untuk sebuah perkampungan yang letaknya di sepanjang Jalan Anyelir, Brawijaya, Asparaga dan Kemuning di Desa Singgahan dan Desa Tulungrejo di Kecamatan Pare Kabupaten Kediri Provinsi Jawa Timur. ${ }^{11}$ Sebuah kampung kecil dengan suasana damai, berhawa sejuk, dan jauh dari bisingnyakota. Penduduk yang tinggal disitu adalah penduduk Indonesia suku Jawa asli. Kampung Inggris bukanlah sebuah kampung tempat dimana orang-orang bule tinggal. Kemungkinan satu atau dua orang bule yang ada disana ada. Kalau pun ada orang bule yang tinggal di kampung

\footnotetext{
${ }^{10}$ Andy Dermawan, dkk, Metodologi Ilmu Dakwah (Yogyakarta: LESFI, 2002), 22.

${ }^{11}$ Hasil wawancara dengan Mr. Hoza (Tokoh Pemuda Kampung Inggris) pada tanggal 22 Juni 2015
} 
Inggris, mungkin wisatawan yang mampir menyumbangkan ilmu mengajar bahasa Inggris atau jadi native speaker di beberapa kursusan bahasa Inggris setempat.

Sebutan Kampung Inggris yang diberikan untuk kampung di Singgahan dan Tulungrejo bukanlah tanpa sebuah alasan yang jelas. Sebab realita yang ada di kampung ini banyak orang yang berbicara menggunakan bahasa Inggris. Namun bukan dikarenakan bahasa Inggris merupakan native language (bahasa asli) orang-orang disitu. Melainkan karena banyak orang yang datang kekampung Inggris untuk belajar bahasa Inggris dan bisa berbicara dalam bahasa Inggris. Di kampung bahasa ini memang banyak sekali terdapat kursusan bahasa Inggris. Hingga awal tahun 2015, tercatat terdapat setidaknya kurang lebih dari 180 Lembaga Kursus bahasa Inggris yang beroperasi di kampung bahasa ini. Bahkan kampung Inggris ini bagaikan telah menjadi sebuah pusat pembelajaran bahasa Inggris yang terbesar di Indonesia. Dengan begitu banyaknya lembaga kursus bahasa Inggris maka tidaklah mengherankan jika banyak orang yang sedang berbicara menggunakan bahasa Inggris dikampung tersebut, mereka tidak lain dan tidak bukan adalah para siswa dan tentor dari lembagalembaga kursus bahasa Inggris. ${ }^{12}$

\section{Proses Belajar Agama Islam}

Didalam Kamus Inggris Indonesia karya John M. Echol dan Hassan Shadily bahwa proses adalah cara untuk melakukan atau membuat sesuatu menuju perubahan yang cukup memakan waktu (methode of doing or making something to move along) ${ }^{13}$

Belajar agama Islam memiliki peran penting dalam dunia pendidikan karena merupakan salah satu pembelajaran yang mengajarkan siswa bertingkah laku yang baik sesuai dengan ajaran agama Islam. Hal lain yang juga sangat penting adalah bahwa belajar agama Islam memberikan pelajaran tentang kejiwaan seseorang sehingga pelajar terutama yang jauh dari pengamatan orang tuanya akan mendapatkan dan mengetahui hal-hal yang mendasar didalam

${ }^{12}$ Hasil wawancara dengan Mr. Gustav (Senior English Teacher In English Village) pada tanggal 23 Juni 2015

${ }_{13}$ John M. Echols, Hassan Shadily, Kamus Inggris Indonesia (Jakarta: PT. Gramedia, 2010), 448. 
dirinya sehingga merasa terawasi atau merasa berdosa ketika akan melakukan hal-hal negatif. Oleh karena itu pentingnya proses belajar-mengajar agama Islam untuk diberikan kepada mereka yang pengetahuan agamanya minim dan jauh dari pantauan orang tua.

Mengajar merupakan suatu perbuatan yang bersifat unik tapi sederhana, karena berkenaan dengan manusia yang pada prinsipnya membimbing manusia dalam sebuah kegiatan yang berprogram dan mengandung makna. ${ }^{14}$ Proses pembelajaran di kelas merupakan hal yang tidak bisa dihindari oleh seorang guru terhadap murid sebagai anak didik baik secara formal maupun non formal. Oleh karena itu mutu pembelajaran yang diberikan guru harus selalu ditingkatkan hal tersebut meliputi penampilan, bahan ajar, dan metode yang dikembangkan dalam proses pembelajaran. Dalam proses belajar mengajar harus ada interaksi antara guru dan muridnya, guru memberikan rangsangan terhadap murid yang meliputi bahan pelajaran yang akan dipelajari, sedangkan murid memberikan reaksi terhadap pelajaran yang diberikan oleh guru. Belajar merupakan suatu proses usaha yang dilakukan seorang untuk memperolah suatu perubahan tingkah laku yang baru secara keseluruhan, sebagai hasil pengalamannya sendiri dalam interaksi dengan lingkungannya. ${ }^{15}$

Perubahan hasil belajar juga bersifat efektif. Maksudnya bahwa perubahan itu tidak akan terjadi dengan sendirinya. Perubahan tingkah laku yang terjadi karena adanya tujuan yang ingin dicapai. Oemar Muhammad Al-Toumy Al-Syaebam menyatakan pendidikan Islam adalah usaha mengubah tingkah laku individu yang dilandasi oleh nilai-nilai Islam dalam kehidupan pribadinya atau kehidupan kemasyarakatan dan kehidupan dalam alam sekitarnya melalui proses kependidikan. ${ }^{16}$ Dengan demikian pendidikan Islam adalah proses dalam membentuk manusia yang mampu mengembangkan potensi yang dimilikinya untuk mewujudkan cita-cita yang diinginkan.

14 Arifin, Hubungan Timbal Balik Dengan Pendidikan Agama Islam (Jakarta: Bulan Bintang, 1987), 172.

${ }^{15}$ Slamet, Belajar dan Faktor Faktor yang Mempengaruhinya( Jakarta: Rajawali Pers, 1997), 02 2005), 08 .

${ }_{16}$ Tohirin, Psikologi Pembelajaran Agama Islam (Jakarta: Rajawali Pers, 
Pendidikan yang dimaksud adalah pendidikan yang berdasarkan alQur'an dan Sunnah Nabi. ${ }^{17}$

Salah satu pengajaran yang bertujuan untuk membentuk dan memberikan dasar-dasar pengetahuan agama Islam bagi pelajar adalah dengan melalui proses belajar agama Islam. Pendidikan Agama Islam secara umum memuat pengetahuan tentang Agama Islamsecara mendasar yang akan menjadi modal bagi siswa sebagai pengantar untuk mendalami ilmu agama secara lebih jauh nantinya.Proses belajar mengajar mempunyai kedudukan dan peranan yang sangat penting, sebab melalui proses belajar mengajar agama Islam dapat dibentuk kepribadian seseorang. Pendidikan agama merupakan salah satu kebutuhan manusia dalam mengembangkan diri sesuai dengan potensi yang ada pada manusia tersebut, dalam hal ini D. Marimba menyatakan bahwa pendidikan adalah bimbingan pimpinan secara sadar oleh si pendidik terhadap pendidikan jasmani dan rohani peserta didik menuju terbentuknya pribadi utama. Berdasarkan pendapat diatas maka dalam proses pendidikan itu terdapat beberapa unsur-unsur, diantaranya unsur usaha (kegiatan dan pelaksanaan), unsur adanya anak didik, unsur adanya pendidikan, dan unsur adanya alat-alat yang dipergunakan. Unsur-unsur tersebut merupakan hal yang menentukan dalam memperoleh hasil sesuai dengan apa yang diinginkan, oleh sebab itu pelaksanaan pendidikan perlu diperhatikan. ${ }^{18}$

Begitu pentingnya pendidikan agama Islam, maka dengan sewajarnya semua pihak yang terkait dengan pendidikan tersebut perlu untuk mendukungnya baik itu guru, orang tua maupun masyarakat. Baik dan tidaknya dukungan dari pihak-pihak tersebut tentu akan berdampak pada baik buruknya proses belajar.Pada dasarnya proses kegiatan pembelajaran itu terdiri dari tiga komponen yaitu terdiri dari pengajar, (dosen, guru, instruktur dan tutor), siswa (yang belajar), dan bahan yang akan diajarkan berfungsi sebagai komunikasi, bahan ajar yang diberikan oleh pengajar merupakan pecan yang akan dipelajari oleh siswa dan seterusnya diadopsi sebagai 1997), 15

${ }^{17}$ Nur Uhdiyati, Pengantar Ilmu Pendidikan Islam (Bandung: Pustaka Setia,

${ }_{18}$ Ahmad D. Marimba, Pengantar Filsafat Pendidikan Agama Islam (Bandung: PT. Ma'rifat, 1974), 19. 
bekal, setelah adopsi dari bahan ajaran yang diberikan oleh pengajar, maka makin banyak ia pelajari selama ia berada dibangku sekolah. Setiap pengajar mempunyai kapasitas mengajar yang berbeda-beda, disamping harus sesuai pula dengan ragam yang disiplin ilmu pengetahuan yang diberikan kepada siswa.

Kegiatan pembelajaran mengandung arti adanya kegiatan interaksi dari tenaga pengajar yang melaksanakan tugas mengajar disuatu pihak dengan siswa/ peserta didik yang sedang melaksanakan kegiatan belajar mengajar dipihak lain, interaksi antara pengajaran dan siswa diharapkan merupakan motivasi, maksudnya bagaimana dalam proses interaksi itu pihak mengajar mampu memberikan dan mengembangkan motivasi serta reinforcement kepada siswa agar dapat melakukan kegiatan belajar secara optimal.Tugas guru sebagai propesi meliputi mendidik, mengajar dan melatih. Mendidik berarti meneruskan dan mengembangkan nilai-nilai hidup. Mengajar berarti meneruskan dan mengembangkan pengetahuan dan teknologi. Sedangkan melatih berarti mengembangkan ketarampilanketerampilan pada siswa. ${ }^{19}$

Tujuan pendidikan Islam adalah menanamkan taqwa dan akhlak mulia serta menegakan kebenaran dalam rangka membentuk manusia yang pribadi, berbudi luhur menurut ajaran Islam. ${ }^{20}$ Sedangkan tujuan pendidikan nasional menurut undangundang No. 20 tahun 2003 adalah mengembangkan potensi anak didik agar beriman dan bertaqwa kepadaTuhan Yang Maha Esa, berakhlak mulia, sehat, berilmu, cakap, kreatif, mandiri" menjadi warga negara yang demokratis dan bertanggung jawab. ${ }^{21}$ Dalam proses belajar mengajar di kampung Inggris sangat diperlukan keefektifan dalam belajar, dan sebagai seorang pendidik jugaharus tahu bagaimana proses pembelajaran yang baik dan tidak baik. Adapun bentuk proses belajar mengajar baik adalah sebagai berikut : (1) Belajar pendidikan agama Islam dengan baik; (2) Tidak terlalu banyak bercanda di dalam belajar; (3) Selalu menghafal apa yang diperintahkan oleh guru, baik 1995), 04.

${ }^{19}$ Moh. Uzer Usman, Menjadi Guru Profesional (Bandung: Remaja Rosdakarya,

${ }^{20}$ Arifin M, Ilmu Pendidikan Islam (Jakarta: Bumi Aksara, 1989), 41

${ }^{21}$ Undang Undang RI No 20 Tahun 2003, Sistem Pendidikan Nasional (Jakarta: Absolut, 2003), 12 
itu bacaan al-Qur'an, ayat-ayat pendek, atau surat-surat penting maupun yang lainnya; (4) Selalu mengerjakan tugas-tugas yang diberikan oleh guru; (5) Selalu rajin masuk pada waktu pelajaran pendidikan agama Islam; (6) Sering belajar bersama bersama teman camp dan berdiskusi tentang pelajaran pendidikan agama Islam

Kemudian di dalam proses belajar ada bentuk atau contoh pembelajaran yang tidak baik yakni: (1) Guru atau murid jarang datang pada waktu belajar pendidikan agama Islam; (2) Selalu punya seribu alasan pada waktu pembelajaran agama Islam dimulai; (3) Selalu ribut dan tidak konsentrasi saat kegiatan proses belajar mengajar sedang berlangsung; (4) Tidak mau mengerjakan tugastugas yang diberikan oleh guru; (5) Tidak mau bertanya kepada guru apabila siswa tidak memahami apa yang disampaikan oleh guru, dan masih banyakhal-hal lain yang tidak baik di dalam proses belajar mengajar agama Islam.

Di dalam proses belajar mengajar bahwa ada lima unsur yang dapat membuat pembelajaran lebih efektif menurut John B. Carrol yakni: (1) Kecerdasan yaitu kemampuan murid pada umumnya untuk belajar; (2) Kemampuan untuk mengerti pelajaran yaitu, kesiapan murid untuk belajar suatu pelajaran yang penting; (3) Ketekunan yaitu sebagian besar hasil dari motivasi murid untuk belajar; (4) Kesempatan yaitu sejumlah waktu yang digunalan untuk belajar; (5) Mutu pembelajaran, pembelajaran yang bermutu tinggi adalah jika murid belajarbahan-bahan pelajaran yang disampaikan secepat kemampuan merekadan tingkat pengetahuan dan keterampilan yang telah ada sebelumnya. ${ }^{22}$

Tujuan merupakan suatu yang sangat penting dalam proses pembelajaran, apalagi dalam pendidikan agama Islam yang menuntut bagaimana anak didik dapat menjadi manusia yang berbudi luhur, bertaqwa kepada Allah SWT dan berakhlak mulia menurut ajaran Islam. Sebagaimana yang dikatakan oleh Al-Abrasyi dalam buku Ahmad Tafsir, bahwa tujuan akhir tujuan pendidikan Islam adalah: (1) Pembinaan akhlak; (2) Menyiapkan anak didik untuk hidup di

${ }^{22}$ Sri Esti Wuryani Djiwandono, Psikologi Pendidikan (Jakarta: Gramedia Widiasarana, 2002), 226. 
dunia dan di akhirat; (3) Penguasaan ilmu; (4) Keterampilan bekerja dalam masyarakat. ${ }^{23}$

Kampung Inggris adalah salah satu lembaga kursusan bahasa Inggris yang ada di dusun Tegalsari Tulungrejo Pare. Lembaga ini berbeda dari lembaga yang lain, karena selain terdapat proses belajarmengajar bahasa Inggris terdapat pula proses belajar-mengajar agama Islam. Hal ini dikarenakan faktor semua guru bahasa Inggris yang ada di Kampung Inggris pernah mengenyam pendidikan agama dengan durasi waktu yang cukup lama.

\section{a. Definisi Agama Islam}

Kata agama dikenal dengan kata din (Arab) dan religi (Latin). Din mengandung arti menguasai, menundukkan, patuh, hutang, balasan dan kebiasaan. Sedangkan religi mengandung arti mengumpulkan, membaca atau mengikat. Kemudian agama diberi arti tidak pergi, tetap ditempat, diwarisi turun temurun, teks, tuntunan dan kitab suci. ${ }^{24}$ Islam menurut bahasa memiliki arti selamat, kedamaian, sentosa. ${ }^{25}$ Sedangkan dalam istilah syar'i Islam berserah diri, tunduk patuh, dengan kesadaran tinggi tanpa paksaan. Sedangkan Islam secara makna, maka akan memiliki arti yang sangat luas jika dikaitkan dengan beberapa arti diatas. Makna dalam arti kata selamat, maka Islam adalah jalan hidup (the way of life) satu-satunya yang paling selamat mengantarkan manusia sampai tujuan akhirnya, yaitu kehidupan akhirat. Dalam konteks perjalanan, tujuan hanya dapat dicapai melalui jalan yang ditempuh. Sedangkan sebuah jalan, ia memiliki cara dan aturan.

Akhirat adalah tujuan akhir dari manusia, cara yang terbaik adalah cara Rasulallah, dan aturan yang digunakan adalah aturan alQur'an dan Sunnah, dan Islam adalah bentuk dari gabungan antara aturan dan cara tersebut yang membentuk jalan yang paling selamat untuk mencapai tujuan akhir dari perjalanan manusia.Jadi, maksud agama disini adalah agama Islam. Satu-satunya agama yang bisa

${ }^{23}$ Ahmad Tafsir, Ilmu Pendidikan dalam Persepektif Islam (Bandung: PT. Remaja Rosdakarya, 1994), 49.

${ }^{24}$ Harun Nasution, Islam Ditinjau dari Berbagai Aspeknya I (Jakarta: UI Press, 1979), 9-10.

${ }^{25}$ A. W. Munawwir, Kamus Munawwir Arab-Indonesia (Surabaya: Pustaka Progressif, 1997), 655. 
mengantarkan tujuan akhir kita, agama yang memberi kedamaian dalam menjalani hidup didunia yang fana ini.

\section{b. Letak Geografis Pare}

Pare adalah sebuah kecamatan di Kabupaten Kediri, Provinsi Jawa Timur. Pare terletak $25 \mathrm{~km}$ sebelah timur laut Kota Kediri, atau 120 km barat daya Kota Surabaya. Pare berada pada jalur KediriMalang dan jalur Jombang-Kediri serta Jombang - Blitar Daerah ini dikenal dengan Kampung Inggris. Nama ini muncul karena banyaknya lembaga-lembaga pelatihan bahasa Inggris yang dikembangkan di daerah ini. Sudah lama ada wacana Pare dikembangkan menjadi ibu kota Kabupaten Kediri, yang secara berangsur-angsur dipindahkan dari Kota Kediri. Namun niat ini tidak pernah serius dilakukan oleh Pemerintah Kabupaten atau para Bupati yang menjabat. (mulai era Bupati H. Sutrisno, Wacana tersebut akhirnya benar-benar dibatalkan, karena akan mendapatkan protes dari warga di sebagian wilayah Kabupaten Kediri, terutama di daerah selatan-seperti Kras, Ngadiluwih, Kandat dan Ringinrejo dan di daerah barat sungai Brantas-seperti tarokan, Grogrol, Banyakan, semen dan Mojo. Sehingga diambil jalan tengah dengan menempatkan Pusat pemerintahan di wilayah Kec. Ngasem Kediri, tepatnya di Ds. Sukorejo (biasa disebut Katang) dan akan juga dibangun Pusat Kota Pare yang berada pada ketinggian 125 meter di atas permukaan laut ini mempunyai udara yang tidak terlalu panas. Berbagai jenis jajanan dan makanan enak dan higenis dengan harga «kampung» dapat dijumpai dengan mudah di kota kecil ini. Berbagai infrastruktur dan fasilitas kehidupan kota juga dengan mudah dapat dijumpai: hotel, rumah sakit (yang besar HVA dan RSUD rumah bersalin yang lengkap pun juga ada), ATM bersama, warnet 24 jam ber-AC, masjid agung, alun-alun, mall dan lain sebagainya.

Pare merupakan kota adipura. Sekolah-sekolah favorit banyak berdiri di kota pare ini dari tingkat TK sampai dengan SMA. Seperti SMP Negeri 2 Pare yang merupakan sekolah bertaraf internasional. Pada tingkat SMA terdapat SMA Negeri 1 Pare dan SMA Negeri 2 Pare yang merupakan SMA kelas Internasional, dan juga ada MA Negeri Krecek.Pare memiliki tanah yang subur bekas letusan gunung Kelud dan tidak pernah mengalami kekeringan. Produk agraria andalan 
dari Pare adalah bawang merah, biji mente dan blinjo. Sedangkan oleh-oleh khas dari Pare antara lain adalah tahu kuning dan gethuk pisang. Di Pare sudah lama bermunculan industri menengah bertaraf internasional, seperti industri plywood dan pengembangan bibit-bibit pertanian. Tempat-tempat rekreasi pun telah ada semenjak tahun 1970-an meskipun sederhana, seperti Pemandian "Canda-Bhirawa» Corah dan alun-alun «Ringin Budo»serta sentral ikan hias di dusun Surowono Desa Canggu.

Kecamatan Pare menjadi terkenal di seluruh dunia karena di sinilah antropolog kaliber dunia, Clifford Geertz - yang saat itu masih menjadi mahasiswa doktoral - melakukan penelitian lapangannya yang kemudian ditulisnya sebagai sebuah buku yang berjudul The Religion of Java. Dalam buku tersebut Geertz menyamarkan Pare dengan nama «Mojokuto». Di Pare, antropolog ini sering berdiskusi dan berkonsultasi dengan Bapak S. Sunuprawiro (alm), waktu itu menjadi wartawan Jawa Pos. Pak Sunu merupakan salah satu narasumber yang membantu antropolog tersebut dalam menyelesaikan bukunya. Pare termasuk kota lama. Ini terbukti dari keberadaan candi dan gua, tidak jauh dari pusat kota, yakni Candi Surowono Dan Gua Surowono. Kedua peninggalan ini membuktikan bahwa Pare telah lahir ratusan tahun lalu. Hanya sampai sekarang belum diketahui dengan pasti kapan kota Pare berdiri dan siapa pendirinya.

\section{c. Sejarah Berdirinya Kampung Inggris}

Awal berdirinya kursus bahasa Inggris di Pare ini tidak lepas dari peran orang yang bernama M. Kalend Osen. Ketika mendengar nama ini tentu anda yang mendengar akan terasa asing. Tidak biasanya orang Indonesia bernama seperti itu, kita cenderung mempersepsikan bahwa nama tersebut identik dengan nama foreigner (orang asing). Apalagi kaitannya dengan bahasa Inggris.Memang banyak orang yang membayangkan bahwa Mr. Kalend (panggilan akrabnya) orangnya tinggi, hidungnya mancung, kulitnya putih, paling tidak orang menyimpulkan beliau foreigner. Pak Kalend adalah orang dari Sebulu, Tenggarong, Kalimantan Timur. Sehingga performance-nya juga tidak jauh dari kita-kita semua.

Mr. Kalend dilahirkan pada tanggal 04 Pebruari 1945. Bermula pada tahun 1976 silam, Kalend Osen adalah seorang santri 
asal Kutai Kartanegara yang tengah menimba ilmu di Pondok Modern Gontor, Ponorogo, Jawa Timur. Menginjak kelas lima, dia terpaksa meninggalkan bangku sekolah karena tidak kuat menanggung biaya pendidikan. Bahkan, keinginannya pulang kembali ke kampungnya gagal karena tiada biaya.Dalam situasinya yang sulit itu seorang temannya memberitahukan adanya seorang ustadz yang bernama K.H Ahmad Yazid di Pare yang menguasai delapan bahasa asing. Kalend muda kemudian berniat berguru dengan harapan minimal dapat menguasai satu atau dua bahasa asing darinya. Ia lalu mulai tinggal dan belajar di Pesantren Darul Falah, Desa Singgahan, milik Ustadz Yazid.

Ustadz Yazid adalah Ahli bahasa yang sangat terkenal saat itu, bahkan banyak mahasiswa yang sengaja datang dari luar kota untuk menemui beliau sekedar ingin belajar bahasa Inggris dari-nya, Ustadz Yazid jugalah yang menyarankan kepada Pak Kalend untuk meneruskan perjuangannya mengajar bahasa Inggris. Sebelum pak Kalend melembagakan kursusannyaBasic English Course (BEC), beliau mengajar bahasa Inggris secara private dari satu tempat ke tempat lain, istilahnya 'no madden'. ${ }^{26}$

Menurut penuturan dari sebagian tokoh masyarakat, seperti Bapak Ruslan (alm), mantan Kepala Desa Pelem (Dusun Singgahan tempat lembaga BEC berada masuk dalam Desa Pelem), Bapak Ahmad Ikhwan, pemangku musholla Al-Ikhwan, Dusun Singgahan, Bapak Drs. H. Hasbi Mursyid, pensiunan guru SMA di Pare, menyatakan hal yang sama bahwa dulu pak Kalend sering mengajar anak-anak di emperan rumah orang kampung atau di serambi masjid Darul Falah, pernah juga di Balai Desa Pelem, kadang-kadang di bawa ke tempattempat bersejarah seperti Candi Surowono, Tegowangi, dan sesekali juga diajak ke lapangan, belajar sambil berolah raga.

Pak Kalend waktu awal-awal mengajar ternyata tidak banyak, sekitar lima sampai sepuluh orang. Itupun yang hadir saling bergantian, jarang istiqomah hadir bersamaan secara penuh di setiap pertemuan. Jadi bongkar pasang. Bahkan pernah siswanya juga habis di tengah jalan.Kita tentu bisa membayangkan betapa susahnya

${ }^{26}$ Hasil wawancara dengan Mr. Kalend Osen (Pendiri Kampung Inggris Pare) pada tanggal 18 Juli 2015 Pukul: 13.00-14.00 Wib 
saat itu untuk mengumpulkan pelajar yang minat dan mau belajar bahasa Inggris! Rata-rata pelajar waktu itu tidak suka bahasa Inggris, karena asumsi mereka bahasa Inggris itu sangat sulit, tidak menarik, bahasanya orang kafir, ditambah lagi lokasinya di daerah terpencil, listrik belum ada.

Meski dengan modal perlengkapan yang sangat terbatas tapi pantang menyerah itulah akhirnya Pak Kalend banyak melahirkan alumni yang akhirnya ikut meramaikan kursusan di Pare hingga mencapai prestasi Luar biasa seperti sekarang ini. Pare terutama Desa Pelem dan Tulungrejo juga dikenal mempunyai potensi pengembangan kursus Bahasa Inggris. Saat ini lebih banyak bermunculan berbagai jenis bimbingan belajar terutama kursus-kursus Bahasa Inggris. Lebih dari 20 buah lembaga bimbingan belajar menawarkan kursus Bahasa Inggris dengan program program D2, D1 atau short course untuk mengisi waktu liburan. Dalam hal ini, kota Pare sebagai pusat belajar Bahasa Inggris yang murah, efisien dan efektif sudah terkenal hingga keluar Pulau Jawa bahkan internasional. Sebagai efek ikutannya, di daerah Tulungrejo sekarang muncul berbagai jenis tempat penginapan dan kost yang menampung para pelajar dan maupun pekerja. Tarif kos yang ditawarkan sangat bervariasi bergantung fasilitas yang tersedia. per orang sekarang yang paling murah 100.000 hingga 500.000.

\section{Paparan Data dan Temuan Penelitian}

\section{a. Kondisi Lingkungan Kampung Inggris}

Dari hasil penelitian yang dilakukan selama Tiga bulan, peneliti menemukan nilai-nilai agama yang masih kental meski ribuan pendatang terus berdatangan.

Hal ini dapat dibuktikan dengan adanya kegiatan sebagai berikut:

1) Diba'iyyah

Kegiatan ini dilakukan setiap malam jum'at mulai habis magrib sampai jam sepuluh malam. Tak jarang warga Kampung Inggris juga mengajak warga pendatang khususnya teman- 
teman yang bermukim di English Learning Area (ELLA) dan juga kursus-kursus yang lain. ${ }^{27}$

2) Tahlil

Warga Kampung Inggris punya kegiatan rutin yang dilaksanakan dalam satu minggu, yakni kegiatan Tahlil. Praktek tahlilan ini di rooling dari satu rumah dengan yang lain. Tujuan dilaksanakanya Tahlilan ini untuk memperat persaudaraan dan saling menjaga Kampung Inggris demi kenyamanan warga pendatang..$^{28}$

3) Khotmil Qur'an

Acara ini dilaksanakan rutin setiap bulan sekali. Dan metode yang digunakan juga dengan cara bergilir dari satu rumah ke rumah yang lain. ${ }^{29}$

4) Pengajian Ibu-ibu

Kegiatan ini dilakukan dalam rentang satu minggu sekali. Kegiatan Ibu-ibu muslimat ini dilakukan setelah dzuhur dengan mengundang penceramah yang handal dalam menyampaikan masalah agama.

5) Pengajian Akbar

Pengajian akbar dilakukan dalam rentang satu tahun dua kali. Pertama dilaksanakan menjelang Maulid Nabi dan yang terakhir menjelang Isra' Mi'raj Nabi. Dana untuk mengadakan pengajian ini diambil dari setiap pertemuan yang diadakan setiap minggu. Namun menjelang bulan terlihat sepi mulai dari aktivitas tahlil, diba'iyyah, Khotmil Qur'an dan pangajian Ibu-ibu muslimat.

6) Wajib Piket

Hal ini dilakukan untuk menjaga nilai-nilai moral Kampung Inggris. Di Kampung Inggris diwajibkan bagi kost putri untuk mengunci pintu kostnya. Semua ini dilakukan untuk menjaga 20.30 wib

${ }^{27}$ Hasil observasi dimasjid Tegalsari pada tanggal 10 Juni 2015 pukul 19.00-

${ }^{28}$ Hasil observasi dirumah Bpk. Kartono pada tangal 15 Juni 2015 pukul 18.30-19.00 wib

${ }^{29}$ Hasil observasi dipondok pesantren Al-Mujahiddin pada tanggal 17 Juni 2015 pukul 07.00-10.00 wib 
citra Kampung Inggris dari hal-hal yang tidak diinginkan. Bila kedapatan anak kost putri berkeluyuran diatas jam sembilan maka akan dikenakan sanksi sesuai yang yang diperbuatnya.

Selain mengadakan penelitian tentang kondisi lingkungan Kampung Inggris terhadap agama, penulis juga mengadakan wawancara dengan tokoh masyarakat, tokoh pemuda, dan kepala desa di Kampung Inggris, hal ini penulis lakukan untuk memperkuat dari hasil penelitian, berikut petikan wawancaranya:

Warga Kampung Inggris sangat religius dan fanatik terhadap agama sebelum adanya kursusan bahasa Inggris. Sempat dulu melarang adanya kursusan bahasa Inggris, hal ini dikarenakan bahasa Inggris adalah bahasanya orang kafir. Meski fanatik terhadap agama, namun nilai kebersamaan saling menghormati antar aliran Islam yang lain masih dijunjung tinggi. Hal ini bisa dilihat sekarang dengan banyaknya aliran Islam di Kampung Inggris mulai dari Nadlatul Ulama, Muhammadiyah, Kejawen, Wahidiyah, LDII, dan Hizbuttahrir. ${ }^{30}$

Setiap ada kegiatan keagaaman Warga Kampung Inggris akan mendukung sepenuhnya. Bukan hanya dari satu aliran Islam, tetapi semuanya akan mendukung. Dan warga Kampung Inggris akan senang bila warga pendatang mengikuti setiap ada acara keagamaan yang dilaksanakan warga Kampung Inggris. ${ }^{31}$ Warga Kampung Inggris akan selalu berusaha untuk menjunjung tinggi nilai-nilai agama. Merupakan menjunjung tinggi nilai-nilai agama dengan terbentuknya karang taruna di Kampung Inggris. Hal ini dilakukan untuk menjaga citra baik Kampung Inggris yang sarat dengan nilainilai religi. ${ }^{32}$

\section{b. Proses belajar agama di Kampung Inggris Pare}

Kampung Inggris adalah kursusan bahasa Inggris yang berbeda dengan kursusan bahasa Inggris yang lain. Guru-guru yang mengajar di Kampung Inggris hampir sebagian pernah mengenyam

\footnotetext{
${ }^{30}$ Hasil wawancara dirumah sesepuh Kampung Inggris tanggal 20 Juni 2015 pada pukul: $19.00 \mathrm{Wib}$ 16.00 Wib.

${ }^{31}$ Hasil wawancara dirumah Bpk. RT Tulungrejo tanggal 22 Juni 2015 pukul:

${ }^{32}$ Hasil wawancara dipost pemuda Kampung Inggris tanggal 30 Juni 2015 pukul: 21. $00 \mathrm{Wib}$.
} 
pendidikan agama di pondok pesantren ternama yang ada dipulau Jawa. Sehingga tidak heran kalau mengajar bahasa Inggris gurunya mengenakan sarung bahkan seperti ditemukan salah satu The Director of ELLA tak pernah sekalipun mengenakan celana kala mengajar bahasa Inggris. Proses belajar agama di Kampung Inggris tidaklah seperti yang ada dipondok pesantren seperti biasanya, yang mengharuskan memakai kopyah dan sarung dan memakai baju dengan lengan panjang. Proses belajar agama di Kampung Inggris bebas mengenakan pakaian tetapi sopan secara syara'. Hal ini dapat dimaklumi karna membernya selalu berganti-ganti setiap bulannya dan dari aliran yang berbeda-beda.

Berikut jadwal kegiatan proses belajar-mengajar di salah satu lembaga dikampung Inggris yaitu English Learning Area (ELLA). ${ }^{33}$

1) Diskusi Agama (Discuss Religion)

Diskusi masalah agama biasa dilakukan setelah sholat magrib sampai jam delapan. Tema yang diberikan selalu berganti-ganti. Biasanya guru menjelaskan didepan dengan menggunakan bahasa Inggris dan membuat kelompok. Masing-masing dari kelompok harus memiliki jawaban yang berbeda dengan jawaban yang lainnya. Disaat menjawab atau memberikan peryataan, peserta harus menggunakan bahasa Inggris, bila tidak maka akan dikenakan sanksi berupa denda perkata sebesar 500 bagi warga baru, dan 1000 bagi warga yang sudah bermukim di ELLA selama satu bulan, dan tidak semuanya mampu menyampaikan dengan bahasa Inggris terlebih bagi warga baru. Ada cara menyampaikan agar terlepas dari denda meski dengan menggunakan bahasa Indonesia yaitu dengan terlebih dahulu mengucapakan " How to say.... atau What is the meaning of...."

2) Mengaji Al-Qur'an

Kebiasaan ini dilakukan setelah menunaikan sholat subuh secara berjamaah di Mushola yang telah tersedia dan dibuka dengan bacaan Basmalah dan terlebih dahulu tutor mengucapakan, "Let's open our reciting holy Qur'an byReciting

${ }^{33}$ Hasil observasi di Kampung Inggris pada tanggal 13 Juni 2015 Pukul: 18.00-20.00 Wib 
Basmalah together". Setelah mengaji bersama-sama kurang lebih satu jam, dilanjutkan dengan materi pelajaran bahasa Inggris. Kegiatan ini diakhiri pada jam 06. 30 dengan diakhiri bacaan Alhamdulillah yang dipimpin oleh guru yang mengajar dengan ucapan, "Let's close our reciting holy Qur'an by reciting Alhamdulillah together...."34

3) Diskusi Antar Camp

Kampung Inggris memiliki banyak Camp dengan materi yang sama. Setiap malam jum'at samua berkumpul di Camp masingmasing untuk membaca Yasin bersama-sama dan dilanjutkan dengan pembacaan Tahlil. Setelah selesai dilanjutkan discuss dengan materi yang berbeda-beda setiap malam jum'atnya. Lebih didominasi dengan tema yang bernuansakan religion dibanding dengan kepemerintahan. kegiatan malam jum'at ini memakan waktu yang cukup panjang dibandingkan dengan kegiatan yang seperti biasanya, yakni dimulai dari habis sholat magrib sampai jam 09. 00.35

Penulis sempat mewawancarai salah satu The advisor of ELLA and the director of ELLA seputar kegiatan yang ada di ELLA yang jauh berbeda dengan kebanyakan kegiatan yang ada dilembaga-lembaga kursus lainya.Logo ELLA berlambang huruf " Nun " sebagai tanda bahwa ELLA bukan semata-mata menjadikan kursusanya untuk mencari finansial semata tapi karna niat Liridhoillah. Impian istri saya kedepannya untuk menjadikan lembaganya agar lebih religius lagi dengan menghafal Al-Qur'an agar istri saya tetap terjaga pula hafalanya sebagai seorang hafidzah. Lembaga ELLA berharap agar masyarakat yang datang ke ELLA bukan mahir dalam hal Speaking, Grammar, Pronunciation dan Vocabularies, tapi juga mahir dalam ilmu agama dan tidak meninggalkan kewajibanya sebagai seorang hamba terhadap Tuhannya. ${ }^{36}$ ELLA menjadi sorotan bagi kursusan lain. Hal ini disebabkan manajemen ELLA yang memadukan antara $06.30 \mathrm{Wib}$

${ }^{34}$ Hasil observasi di Kampung Inggris pada tanggal 18 Juni pukul: 04.30-

${ }^{35}$ Hasil observasi di Kampung Inggris pada tanggal 12 Juni pukul: 18.00$21.00 \mathrm{Wib}$

${ }^{36}$ Hasil wawancara dengan Director of ELLA di ELLA office pada tanggal 18 Juni 2015 pukul: $10.30 \mathrm{Wib}$ 
kegiatan Kursus bahasa Inggris dengan agama. Selain mendapatkan ilmu bahasa Inggris, warga ELLA juga mendapatkan ilmu agama. Baru dua tahun ELLA berdiri namun data member yang mendaftar di ELLA lebih dari lima ribu orang. Banyak dari kursusan lain yang ikut gabung di ELLA hanya untuk mengetahui dibalik kesuksesan ELLA dan kebanyakan dari mereka menyimpulkan bahwa kesuksesannya karna menanamkan nilai-nilai agama. ${ }^{37}$

\section{Peran Lingkungan Kampung Inggris Terhadap Proses Belajar Agama}

Lingkungan Kampung Inggris memiliki peran besar terhadap berlangsungnya proses belajar mengajar Agama di setiap lembaganya. Hal ini dapat dibuktikan dengan seringnya warga Kampung Inggris meminta guru dari salah satu lembaga kursus untuk memimpin acara keagamaan dan mengajak siswa kursus setiap ada acara keagamaan seperti tahlil, khotmil Qur'an, Marhaban, Tadarrusan dan Taraweh bersama dibulan puasa. Seringkali warga Kampung Inggris memberi makanan atau minuman disela-sela kegiatan keagamaan sedang berlangsung. Tokoh masyarakat dusun Tegalsari menyatakan bahwa dirinya dan warga sekitar mendukung sepenuhnya dengan kegiatan yang ada di Kampung Inggristerutama dalam hal agama. Warga Kampung Inggris yang berdekatan dengan lembaga kursusan hampir semuanya mengenal siswanya. Hal ini dikarenakan ada rasa saling menghormati satu sama lain dan saling berlomba-lomba untuk menanamkan etika baik.

Warga Kampung Inggris khususnyadusun Tegalsari mengharapkan pendidikan yang ada disini (Kampung Inggris) tidak hanya mendalami ilmu Bahasa Inggris, namun juga ilmu agama dan etika harus dijaga. Kehadiran lembaga kursusan yang menanamkan nilai-nilai agama didukung sepenuhnya oleh warga dan para pemuda. Dengan adanya lembaga kursusan anak-anak dan remaja dusun Tegalsari bisa belajar Bahasa Inggris dan belajar masalah agama.

${ }^{37}$ Hasil wawancara dengan Advisor of ELLA di Country Camp pada tanggal 18 Juni 2015 Pukul: 16.00 Wib 


\section{Simpulan}

Menurut hasil penelitian, siswa yang telah mengikuti program dilembaga pendidikan bahasa Inggris di Pare ini dapat meningkatkan kemampuan bahasa Inggris mereka. Tidak hanya meningkatnya kemampuan namun juga pengetahuan bahasa Inggris bertambah serta lebih percaya diri dalam menggunakan bahasa Inggris. Dan juga tak kalah penting peran keagaaman di kampung Inggris sangatlah berperan dalam keseharianya.

Pencapaian yang baik dari siswa, minat masyarakat yang tinggi untuk mengikuti kursus di Pare dan munculnya lembagalembaga yang profesional dapat dijadikan indicator keberhasilan sebuah kampong Inggris. Adapun kondisi lingkungan Kampung Inggris (English Village) adalah sebuah desa yang ada dikecamatan Pare tepatnya didesa Pelem dan Tulungrejo. Kedua desa ini masih menjunjung tinggi nilai-nilai agama meski dipenuhi ribuan pendatang yang ingin mendalami ilmu bahasa asing (English, Arabic, Mandarin danJapan). Hal ini dapat dibuktikan dengan banyaknya kegiatan keagamaan seperti: Diba'iyyah, Tahlil, Khotmil Qur'an, Pengajian Ibu-ibu Muslimat, Pengajian Akbar, Wajib Piket dan lain-lain.

Sedangkan Proses belajar agama di kampung Inggris adalah proses perubahan yang terus menerus pada diri manusia, karena usaha untuk mencapai di atas bintang cita-citanya dan falsafah hidupnya. Belajar merupakan suatu kegiatan yang berlangsung secara kontinyu, dimulai sejak manusia lahir dan meliputi tentang banyak hal. Berbagai hal mulai dari yang kecil sampai hal-hal yang besar dapat dikatakan sebagai proses belajar. Berikut kegiatan belajar agama di Kampung Inggris Pare: a. Diskusi agama (Discuss religion). b. Mengaji Al-Qur'an (Recite holy Al-Qur'an). c. Diskusi antar Camp (Discuss between the other Camp).

Peran Lingkungan Kampung Inggris Terhadap Proses Belajar Agama di kampung Inggris, merupakan Lingkungan pendidikan yang kondusif dan juga lingkungan yang dapat membangkitkan semangat belajar dan menjadi faktor pendorong yang dapat memberikan daya tarik tersendiri bagi proses belajar. Kampung Inggris adalah perkampungan yang sejuk yang warganya memiliki karakter lemah lembut. Diantara peran Kampung Inggris terhadap Kampung Inggris 
yaitu: a. Menjunjung tinggi nilai-nilai agama, b. Memberi contoh yang baik bagi semua warga, dan Memiliki kepedulian yang tinggi terhadap warga setempat[.]

\section{REFERENSI}

al-Nahlawi Abdurrahman, Pendidikan Islam di Rumah, Sekolah, dan Masyarakat Jakarta: Gema Insan Press, 1995.

Al-Qardhawy Yusuf, Pendidikan Islam dan Madrasah Hasan Al-Banna Jakarta:Bulan Bintang, 1980.

Arifin, Hubungan Timbal Balik Dengan Pendidikan Agama Islam Jakarta: Bulan Bintang, 1987.

D. Marimba Ahmad, Pengantar Filsafat Pendidikan Agama Islam Bandung: PT. Ma' rifat, 1974.

Departeman Pendidikan dan Kebudayaan, Bimbingan dan Penyuluhan Jakarta: Gaya Tunggal, 1980.

Dermawan Andy, dkk, Metodologi Ilmu Dakwah Yogyakarta: LESFI, 2002.

Djiwandono Sri Esti Wuryani, Psikologi Pendidikan Jakarta: Gramedia Widiasarana, 2002.

H. A. Rusdian \& Yaya Suryana, Pendidikan Multikultural, Bandung :CV Pustaka Setia, 2015.

Hamalik Oemar, Proses Belajar Mengajar Jakarta: PT Bumi Aksara, 2009.

Hasbi Lawrens,Burhani MS, Kamus Ilmiah Populer Jombang: Lintas Media, 2001.

Hassan Shadily, John M. Echols, Kamus Inggris Indonesia Jakarta: PT. Gramedia, 2010.

M Arifin, Ilmu Pendidikan Islam Jakarta: Bumi Aksara, 1989.

Munawwir A.W., Kamus Munawwir Arab-Indonesia Surabaya: Pustaka Progressif, 1997.

Nasution Harun, Islam Ditinjau dari Berbagai Aspeknya I Jakarta: UI Press, 1979. 
Rosyadi Khoiron, pendidikan profetik Yogyakarta: Pustaka Pelajar, 2004.

Sabri Ahmad, Strategi Belajar Mengajar Micro Teaching, Padang: Quantum Teaching, 2007.

Slamet, Belajar dan Faktor Faktor yang Mempengaruhinya Jakarta: Rajawali Pers, 1997.

SM Ismail, dkk, Paradigma Pendidikan Islam Yogyakarta: Pustaka Pelajar, 2000.

Tafsir Ahmad, Ilmu Pendidikan dalam Persepektif Islam Bandung: PT. Remaja Rosdakarya, 1994.

Tohirin, Psikologi Pembelajaran Agama Islam Jakarta: Rajawali Pers, 2005.

Uhdiyati Nur, Pengantar Ilmu Pendidikan Islam Bandung: Pustaka Setia, 1997.

Undang Undang RI No 20 Tahun 2003, Sistem Pendidikan Nasional Jakarta: Absolut, 2003.

Usman Moh. Uzer, Menjadi Guru Profesional Bandung: Remaja Rosdakarya, 1995. 
